\title{
LICENSE AGREEMENTS: SEGMENTATION WITHIN THE INTERNATIONAL MARKET \\ OF SEEDS
}

LINA MARÍA DÍAZ VERA*

\section{INTRODUCTION}

Seeds are encapsulated plant embryos; their nature is to grow into new plants if there are appropriate conditions. Producing food for the growing human population demanded increases in yields that will hardly meet with the traditional methods of plant breeding. Biotechnology provided the means to create seeds tolerant to herbicides, weeds, and droughts. However, seeds are still seeds, they will reproduce themselves and provide to their offspring the improvements genetically introduced in them if they are properly nourished and regardless of the country they are in.

The self-replicating nature of seeds challenges the very essence of IP rights. The rationale behind IP rights is to secure commercial exclusivity to recoup the investment made in creating new technologies. But how to recover the huge investment made to identify a particular gene that will render a plant resistant to herbicides, if by selling a single seed identical copies will naturally grow from it. License agreements provide a legal solution. Instead of directly commercializing final seeds, licensing the fragmented use of genetic traits, indispensable for the creation of transgenic seeds, enables the worldwide distribution of technologies as well as the charge of fees all along the value chain.

License agreements can be concluded between parties located in different countries for the conduction of just one or several of the activities required to introduce a gene into a cultivable seed. They may also include ancillary provisions restricting the business of the licensee by fencing the territory where it is allowed

* Abogada de la Universidad Externado de Colombia con Maestría en Derecho con énfasis en Propiedad Intelectual y Derecho de la Competencia de London School of Economics. Abogada en la Superintendencia de Industria y Comercio en la Delegatura para la Protección de la Competencia, Bogotá, Colombia. Contacto: lmdiazvera@gmail.com Fecha de recepción: 22 de marzo de 2017. Fecha de aceptación: 18 de mayo de 2017. Para citar el artículo: Díaz-Vera, L. M. "License agreements: Segmentation within the international market of seeds", Revista La Propiedad Inmaterial n. ${ }^{2}$ 23, Universidad Externado de Colombia, enero-junio 2017, pp. 19-45. Dor: https://doi.org/10.18601/16571959.n23.02 
to exploit the technology and prohibiting the importation or exportation of it. Such restrictions might hinder the ordinary course of international trade as well as the development of competing technologies. This paper aims to evaluate how different jurisdictions have had address the anticompetitive practices employed to enlarge the scope of national IP rights and capture fees through license agreements.

The first section of this paper describes the scene in the international market of seeds, how it became such a concentrated market, the decisive role of IP rights within it and the interplay between patent holders, plant breeders and farmers within the market of seeds. Secondly, it will be explained why multinationals impose restrictions on international markets; to then approach case law from the European Union, United States, Brazil and Argentina, searching for different solutions to this issue. The final section concludes.

\section{The INTERNATIONAL MARKET OF SEEDS}

\section{I.I. GENERAL BACKGROUND}

The advent of biotechnology reshaped the scene of agriculture ${ }^{1}$. The possibility of modifying plant's genetic information to make them resistant to pesticides and herbicides increased agriculture's productivity and profits. Artificial hybridization and genetic use restriction technologies (GURTs), overthrow natural barriers for the entry, expansion, and consolidation of multinational enterprises in the seed market. Artificial hybridization forces farmers to constantly purchase seeds to preserve the levels of yields achieve in previous harvest, as those corps do not present the same yield when reproduced from seeds of previous harvest ${ }^{2}$. Recently, GURTs barriers the movement of genes between plants, making possible to limit the expression of desirable traits in the offspring of genetically modified corps ${ }^{3}$. Again, it forces farmers to purchase seeds once and again. These technologies create a demand for indispensable inputs that used to be freely available for farmers ${ }^{4}$.

The yield improvements brought by biotechnology incentivize the adoption of these technologies. According with the International Service for the Acquisition of Agri-biotech Applications, during the last 20 years the biotechnology implementation in agriculture increased crop yields by $22 \%$, profits by $68 \%$, and alleviated

1 Kloppenburg, Ralph Jack, First the seed: The political economy of plant biotechnology, University of Wisconsin Press, 2004.

2 Ibid., 93.

3 Lence, Sergio H. and others, "Welfare impacts of intellectual property protection in the seed industry", American Journal of Agricultural Economics, 2005, 87(4), pp. 951-968.

4 Srinivasan, C. S. and Thirtle, Colin, "Potential economic impacts of terminator technologies: policy implications for developing countries", Environment and Development Economics, 2003, 8(01), pp. 187-205. See also: Yusuf, Mansir, "Ethical issues in the use of the terminator seed technology", African Journal of Biotechnology, 2010, 9(52), pp. 8901-8904. 
poverty by more than 16.5 million small farmers ${ }^{5}$. The implementation of biotechcorps is high in developed and developing countries. The United States (U.S.) leads globally the authorization for the cultivation of biotech crops ${ }^{6}$, whereas Brazil, Argentina, China, India and South Africa lead within their respective continents ${ }^{7}$.

The demand for technological improvements in the seed industry pressures companies to develop the next cutting-edge technology ${ }^{8}$ which requires high investments in research and development activities (Herein after R\&D). Between 2010 and 2014 the overall cost of discovering and developing a product to protect crop was up to $€ 215$ million $^{9}$; it takes 11.3 years $^{10}$, and requires to research and synthesize over 159.754 possible products of which only one is launch ${ }^{11}$. Therefore, developing the next blockbuster product, recoup the investment and gather enough resources to fund the following generation of technologies poses huge pressures upon multinationals.

The rush to develop new biotech products triggered a series of mergers and acquisitions resulting in a highly-concentrated industry. During the 1980's to 1990's the agricultural biotechnology industry (ag-biotechnology) went through a "transitional phase" with a series of mergers and acquisition among several companies which used to offer different products ${ }^{12}$. It ends up with transgenic plants flooding the market ${ }^{13}$ and with BASF, Bayer, Dow, DuPont, Monsanto and Syngenta becoming into the Big Six firms, which globally dominate the market. Three of them might engage in further integrations: DuPont announced its merger with Dow ${ }^{14}$ and Bayer plans to buy Monsanto ${ }^{15}$. Competition authorities in the

5 International Service for the Acquisition of Agri-biotech Applications. ISAAA Brief 49-2014: Top Ten Facts. Available at: at http://www.ISAAA.org/resources/publications/ briefs/49/toptenfacts/default.asp

6 International Service for the Acquisition of Agri-biotech Applications ISAA. ISAAA Brief 49-2014: Global Status of Commercialized Biotech/GM Crops: 2014. Available at: http://www.ISAAA.org/resources/publications/briefs/49/executivesummary/default.asp. See also U.S. Department of Agriculture. Genetically Engineered Crops in the United States, 2014. Available at: http://www.ers.usda.gov/media/1282246/err162.pdf

7 Ibid.

8 Kloppenburg, R. J. (n1), pp. 297-300. See also Syngenta Cp / Advanta (Case Comp/M.3465) [2004] Document No 32004M3465. OJ C 263/7 \$ 46.

9 McDougall, Phillips. "The Cost of New Agrochemical Product Discovery", Development and Registration in 1995, 2000, 2005-8 and 2010 to 2014 . R\&D expenditure in 2014 and expectations for 2019, 2016. Consultancy Study for CropLife International, CropLife America and the European Crop Protection Association. Available at: http://www.croplifeamerica.org/wp-content/uploads/2016/04/Phillips-McDougall-Final-Report_4.6.16.pdf 12.

10 Ibid., 19.

11 Ibid., 18.

12 Новвs, Jill E. "The private sector: mNes and smes", in Smyth and others (eds.), Handbook on Agriculture, Biotechnology and Development, Edward Elgar, 2014, 57. 13 Ibid., 58.

14 Benoit, David; Cimilluca, Dana; Mattioli, Dana and Bunge, Jacob, "Dow Chemical and DuPont are in Advanced Talks to Merge", Wall Street Journal, 2015. Available at: http://www.wsj.com/articles/dow-chemical-and-dupont-are-in-advanced-talks-to-merge-1449621799

15 Bunge, Јасов and Mattioli, Dana, "Bayer Proposes to Acquire Monsanto", Wall Street Journal, 2016. Available at: http://www.wsj.com/articles/bayermakestakeoverapproachtomonsanto 1463622691 
U.S. ${ }^{16}$ and Europe ${ }^{17}$ have conditioned integrations among those companies to the licensing and sale of assets required for developing ag-biotech products to preserve adequate levels of competition.

\section{I.2. The IMPACT OF IP RIGHTS RECOGNITION}

The recognition of IP rights over ag-biotechnology inputs, due to multilateral trade agreements, is the glue holding the international seeds market together. Thanks to the Agreement on Trade-Related Aspects of Intellectual Property Rights (TRIPS), microorganism patentability became an international threshold as well as the protection of plant varieties ${ }^{18}$. Although there is no international consensus about whether plants and living matter should be patentable ${ }^{19}$, TRIPs mandates to protect them through IP regimes setting the ground field for biotechnology development.

The International Convention for the Protection of New Varieties of Plants (UPOv) design to protect new, distinct, stable, and uniform plant varieties ${ }^{20}$ has been implemented in many countries to fulfil TRIPS mandate. Though, Plant Breeder's Rights (P.B.R.) protection is substantially different to the one provided by patents. Depending on the version of the Treaty each country had adopted, whether it was Upov 1978 or 1991, P.B.R. can be subject to one or both of the following exceptions: the farmer's privilege and the plant breeder's exception, by which farmers and plant breeders are entitled to use the plant without prior authorization ${ }^{21}$. Patents are not subject to these exceptions.

Considering that patent's essence is to allow its holder to exclude others from "making, using, offering for sale, selling, or importing for these purposes" the protected product ${ }^{22}$. Creating a genetically modified seed involves three basic stages which raw material are genetic traits, which is normally patented by multination$\mathrm{als}^{23}$. Those stages are: development, multiplication and, commercialization. At the development stage, the germplasm containing the desirable trait, like herbicide tolerance, is introgress into a parent or basic seed stable enough for cultivation. At the multiplication stage, the parent seed is propagated to a commercial scale, to be marketed among farmers, food processors, retailers, etc. Therefore, all the

16 U. S. Department of Justice. Press Release. Justice Department Approves Monsanto's Acquisition of Dekalb Genetics Corporation, 1998. Available at: www.usdoj.gov

17 Syngenta Cp / Advanta, 2004, (n. 8) \$ 106.

18 Cf. Trips, Article 27(3).

19 World Trade Organization. The Relationship Between The Trips Agreement and The Convention On Biological Diversity Paper, 2006. Available at: https://www.wto.org/ english/tratop_e/trips_e/ipcw368_e.pdf

20 Cf. International Convention for the Protection of New Varieties of Plants. United Nations, 1991, Article 5.

21 Ibid., Article 15. 2.

22 Cf. Trips, Article 28.

23 Harl, Neil E., “The Age of Contract Agriculture: Consequences of Concentration in Input Supply", Journal of Agribusiness, 2000, 18(1), 115-128. See also Lim, Daryl, "Living with Monsanto", Michigan State Law Review, 2015, 559-663. 
stages fall within the realm of patentee entitlement to exclude others from using the germplasm; albeit, without the seed the germplasm is useless.

Each stage requires advanced knowledge and specialization. In fact, the spread use of ag-biotechnology and genetically modified seed gave way to the emergence of new and specialized players: seed growers and conditioners, and plant breeders ${ }^{24}$. These new actors condition trait and seeds to the weather and pests' conditions of different geographic areas ${ }^{25}$. A trait might be useful in several countries and corps; it might be desirable to allow plant breeders located in different countries to develop a parent seed cultivable in different territories.

However, IP rights are territorial, they are granted country by country to be effective within the territory of the issuing State. There are international treaties to facilitate the recognition of such rights but none of them grants a global-wide protection ${ }^{26}$. The initiative to create a unitary patent for Europe has been discuss for decades and, although Regulation n. ${ }^{0} 1257 / 2012^{[27]}$ would make it possible, it is not yet a reality. In the meantime, nothing impedes a patentee from licensing with a plant breeder located abroad, authorizing him to use the trait.

Unlike patents and P.B.R, genetics is universal and perpetual. A gene resistant to herbicides will keep its properties regardless of its location, and such feature will pass into its offspring until another genetic modification occurs. Furthermore, due to the natural self-reproduction of seeds, no reverse engineer process is needed to replicate the trait, the seed will grant access to it. It becomes evident, that without a legal or natural measure to prevent third parties from replicating the seed, once it is sold for the first time, there would be no incentive to pay for it repeatedly.

The case of Bowman v. Monsanto ${ }^{28}$ illustrates the above. Bowman purchased soybean seeds intend for human or animal feed; the seeds had herbicide traits patented by Monsanto; Bowman replanted the seeds without paying fees nor concluded any agreement. Still, the seed was herbicide tolerant and Bowman replanted it for some years before being suit by Monsanto.

The territorial scope of patents and P.B.R, along with the universal reach of genetics, creates many concerns regarding licenses' enforcement and execution among parties situated in countries different from the one issuing the IP right.

24 Commission on genetic resources for food and agriculture. Food and Agriculture Organization of the United Nations. Potential impacts of genetic use restriction technologies (gurtS) on agrobiodiversity and agricultural production systems, 2001, FAO. Available at: ftp://ftp.fao.org/docrep/fao/meeting/015/aj627e.pdf 19.

25 In the case of Nungesser v Commission, Nungesser developed seeds of maize to be cultivated at climatic conditions where it had been considered unsuitable for its cultivation. Cf. Case C-258/78. L. C. Nungesser v Commission, 1982, ECR 02015.

26 Patent Cooperation Treaty. Chapter I. International Application and International Search.

27 Council and Parliament Regulation (EU) 1257/2012 of 17 December 2012. Implementing enhanced cooperation in the area of the creation of unitary patent protection, 2012, OJ L 361/1.

28 U.S. Supreme Court. Vernon Hugh Bowman v. Monsanto Company et al. 569 U. S. ____ (2013) 5 ss. 
For instance, does it constitutes patent infringement to use the technology in a country where no patent has been granted. Is the licensor entitled to impede the licensee from exporting the trait or the products thereof to a country commercially appealing both of them but where no patent has been granted ${ }^{29}$. These issues touch with the scope of IP rights over subsequent commercialization of the technology, there is no international consensus in this matter, creating uncertainty about the international extension of patents and P.B.R. by means of licenses.

\section{LICENSING PRACTICES AND SEGMENTATION OF INTERNATIONAL MARKETS}

\section{I. TERritorial RESTRICTIONS AND FRAGMENTED AUTHORIZATIONS}

License agreements vary according with the requirements of the parties and the activities each of them performs. The license might be transferable, assignable, exclusive and limited to a specific territor ${ }^{30}$. Notwithstanding those particularities, license's main effect is to allow the licensee to perform all, or at least one of three basic activities: development of basic seeds, production, commercialization of cultivable seeds. It might include clauses for each of those basic activities, e.g, during the development stage, there are back clauses for the multinational to have access to the records and binnacles; at the commercialization stage, promotion obligations force the licensee to stimulate the purchase of products manufactured by the licensee ${ }^{31}$. Also, these products normally complement the trait licensed: as it is well-known, Monsanto's Roundup Ready seeds were tolerant to the Roundup herbicide sold by the same company, while BASF's Clearfield Rice is tolerant to BASF's Clearfield herbicide.

The promotion might imply just providing information about the advantages of using both products together ${ }^{32}$, it can also ty the sale of the seed to the purchase of the complementary product ${ }^{33}$ or even force farmers to conclude stewardship agreements to purchase the seeds. These stewardship agreements implement an ongoing oversight and guidance on how to use the technology for its adequate implementation, performance and dissemination ${ }^{34}$. it will state how the farmer

29 Case C-193/83 Windsurfing Intl. Inc. v Commission, 1986, Ecr, p. 611.

30 Neagley, Clinton H., "Patent Licensing for Small Agricultural Biotechnology Companies", in Intellectual Property Management in Health and Agricultural Innovation: A Handbook of Best Practices, MIHR and PIPra, 2007, p. 216.

31 Leach, Mark; Mesquita, Luiz and Downey, David, "Case study: Partnering strategies in a bio tech. world: The case of Dairyland Seed Company", The Journal of Business \& Industrial Marketing, 2001, 16(3), p. 226.

32 Ibid.

33 Clause 4(t) Grower agrees. Monsanto Technology/Stewardship Agreement (Limited Use License). 2016 In Monsanto. 2016TUG U.S. Technology Use Guide and Irm Overview. (38). Available at: http://www.monsanto.com/products/documents/2016_tug_final.pdf See also David A. Hennessy. Dermot J. Hayes. Competition and Tying in Agrichemical and Seed Markets. [2000] 22(2) Review of Agricultural Economics, 389-406.

34 Cahoon, Richard S., "Licensing Agreements in Agricultural Biotechnology", in Intellectual Property Management Intellectual Property Management in Health and Agricultural Innovation: A Handbook of Best Practices, MIHR and PIPRA 2007, p. 1013. 
should control pests and weed $s^{35}$ and prohibit the reuse of seeds $s^{36}$. It will also include the payment of fees over any IP right embedded within the seed: patents and P.B.R. ${ }^{37}$.

Following the above, licenses over traits normally have two features: the authorizations granted are fragmented and limited to a clearly determine territory, sometimes with exclusivity. A license will never grant the licensee complete and absolute freedom to use and commercialize the trait, to the opposite and as was explain earlier, the license is employed to grant the multinational certain control over subsequent stages of seed development and commercialization. Equally, territorial restrictions imposed upon all and each party involved impede licensors to conduct the authorized activities out of the territory specified in agreement, hence they cannot compete with other licensees to which other territories have been allocated. The territory might be a single or several countries and they may or not coincide with country where the patent was granted.

As the next section will develop further, the explanation behind those licensing practices is twofold: firstly, the self-reproduction nature of seeds makes impossible to license only the right to use the seed and, afterwards, return it to the patentee, using the licensed technology, the seed, necessarily implies its full consumption ${ }^{38}$. Secondly, the IP right might terminate with the first sale of the seed containing the trait, as long as the seeds are licensed instead of sold, the patentee will be able to interfere in and profiting from subsequent stages of commercialization ${ }^{39}$. Behind licensing restrictions is the fear of losing control over the IP rights.

\subsection{UNCERTAINTY OF EXHAUSTION}

The exhaustion doctrine determines a substantial part of IP rights scope: the point on which the right to exclude others from using and commercializing an item containing the invention terminates. It is important to notice that exhaustion does not annuls the IP right itself, it would remain valid until a judgement decides otherwise or until 20 years pass. The exhaustion doctrine only concerns the control upon particular items containing the invention protected.

In general terms, the 'item's first sale' exhausts the patent regardless of whether it is made directly by the patentee or with his approval, i.e., licensee authorized to sell. Thus, the IP right holder receives a reward from its creativity but is also

35 Monsanto. 2016тug U.S. Technology Use Guide and Irm Overview. (3-5) Available at: http://www.monsanto.com/products/documents/2016_tug_final.pdf

36 вASF Corporation. Clearfield Wheat Stewardship Guide 2014-2015. (2) Available at: http://agproducts.BASF.us/products/research-library/clearfield-wheat-stewardship-guidelines. pdf See also: Clause 4(f) and 4(g) Grower agrees. 2016 Monsanto Technology/Stewardship Agreement (n. 33).

37 Ibid., Clause 4(s).

38 Lim, D., (n. 23) 603.

39 Winston, Elizabeth I., "Why sell what you can license?", George Mason Law Review 9, 2006, p. 14. 
refrain from seeking continuous payments for each transaction over the item ${ }^{40}$. There is no international consensus about the acts triggering the exhaustion, what constitutes a sale, whether post-sale restrictions in licenses could circumvent the exhaustion, nor about the geographic effects of it. Actually, countries have carte blanche to shape exhaustion as they see fit, as it was excluded from TRIPS ${ }^{41}$.

In the U.S., for instance, exhaustion is trigger by the first sale which can be conditional or restricted to one or several of the rights granted by the IP right. As mentioned, patents grant various rights: to offer for sale, sale, use, make, import the invention ${ }^{42}$. The IP holder may waive those rights partially or completely by transferring just one or several of them through licenses. As long as the sale is conditional, the patent is not exhausted because the rights are not waived completely ${ }^{43}$. Inversely, using the item for a purpose different from the one authorized constitutes patent infringement ${ }^{44}$.

Again, Bowman v. Monsanto illustrates how conditional sales circumvent the exhaustion of IP rights. Bowman replanted seeds intended for consumption, not for harvest. Because of the exhaustion, the patentee is not entitled to extract further economic rents from downstream commercialization of the seed; albeit the purchaser is neither entitled to replicate the patented item ${ }^{45}$, as patent rights "revives" after the sale of the seed, if it is reproduced for growing purposes rather than used as a commodity ${ }^{46}$. When dealing with patents upon living matter capable of self-reproducing. Such construction of the exhaustion doctrine could render final seed consumers as infringers of IP rights they ignored ${ }^{47}$, creating uncertainty upon the scope of the IP rights and the legitimacy of further transactions upon protected items.

The geographical reach of the doctrine is also uncertain. Some countries apply a national exhaustion doctrine, meaning that the first sale of the item will exhaust the right only within that country ${ }^{48}$; therefore, it is possible to impede parallel imports of an item manufactured abroad. Others countries have adopted an international exhaustion rule under which, once the item is sold for the first time, the IP rights over it would be exhausted around the world, and it would not be possible to prevent importations because IP rights infringement ${ }^{49}$.

40 Lim, D., (n. 23) 608.

41 Cf. trips, Article 6.

42 U.S. Court of Appeals of the Federal Circuit. Mallinckrodt, Inc. v. Medipart, Inc., 976 F. 2d 700. (1992).

43 Ibid., 17.

44 Ibid., 21.

45 Bowman v Monsanto (n. 28) 10.

46 Ibid.

47 Lim, D., (n. 23) 592.

48 Forsyth, Miranda and Warwic, Rothnie, "Parallel Imports", in Steven D. Anderman (ed.), The Interface Between Intellectual Property Rights and Competition Policy, Cambridge University Press, 2007, p. 430.

49 Ibid. 
On the other hand, the European exhaustion doctrine is sui generis: it states that patents are exhausted whenever the item "has been lawfully distributed on the market in another Member state by the actual proprietor of the right or with his consent" ${ }^{\prime 50}$. It aims to foster the free movement of goods within the European Economic Area (E.E.A) by avoiding undue restrictions arising from the territoriality of national IP rights ${ }^{51}$. As said earlier, IP rights granted by each Member States and by European Patent Office have territorial scope, meaning that the holder of national or European patents could prevent importations which might constitute an infringement of its rights. For example, a patentee could prevent the importation of an item manufactured under a license in country $A$ to the territory of country $\mathrm{B}$, alleging that it is an infringement of its patents in country $\mathrm{B}$. Without the exhaustion doctrine, IP rights territoriality will render nugatory the establishment of a single market within Member States ${ }^{52}$.

Altogether, the uncertainty surrounding the exhaustion of national IP rights facilitates the erection of artificial boundaries for international trade. The imposition of export and import restrictions and conferring absolute territorial protection may be without the scope of IP rights in the relevant territory, as grating open exclusive licenses agreeing not to compete with the licensor within a specific territory. Thus, patent holders could distort competition in foreign markets by means of license agreements.

There is nothing new in license agreements hampering international trade. TRIPS Article 40 recognizes that certain licensing practices might restrict international trade and technology transfer; moreover, it provides that countries may implement appropriate measures to prevent such practices. Beyond this provision, there is no much guidance about which license practice might be abusive nor regarding the measures member states could implement. There have been initiatives for Draft International Antitrust Code, but these have failed to reach international consensus $^{53}$. However, the application of competition law regimes in the importing country might offer a solution to the segmentation of international markets.

\subsection{National antitrust Regimes COUld OfFer a SOlution}

As has been discuss, anticompetitive license agreements not always involve undertakings located in the same country nor within the boundaries of the country affected by it, also the dominant position is held not within the internal market

50 Case C-61/97, FDV v Laserdisken, 1998, ECR I-05171 \$ 13.

51 Westкamp, Guido, "Intellectual Property, Competition Rules, and the Emerging Internal Market: Some Thoughts on the European Exhaustion Doctrine", 11 Intellectual Property L. Rev., 2007, p. 317.

52 Cf. Treaty Establishing the European Community, of 10 November 1997. O.J. C 340/112. Article 30. See also Nungesser v. Commission (n. 25), pp. 2033 ss.

53 Finentscher, Wolfgang, "The Draft International Antitrust Code (Diac) in the Context of International Technological Integration - The Institutional and Jurisdictional Architecture", 72 Chi.-Kent. L. Rev., 1996, p. 533. 
but in the international one. Nevertheless, the anticompetitive effect and inefficiencies might hinder a particular national market. Therefore, the effect doctrine entitles national authorities to judge under their national competition law regime anticompetitive behaviors originated beyond their frontiers to protect the internal market $^{54}$.

The motivations of each country to apply or not its competition law to IPagreements restricting international trade vary ${ }^{55}$. Firstly, because the effects of an anticompetitive restriction to international trade might not be seen in the exporting country with jurisdiction over the company imposing such restrictions. Secondly, countries might not challenge such restrictions in order to support international trade activities of their nationals, for instance, to help them circumvent international exhaustion rules that might lessen their possibilities of profiting for international markets ${ }^{56}$, which might be disadvantageous compared to national exhaustion rules applied in other jurisdiction ${ }^{57}$.

In a similar vein, the importing country might have strong incentives to use its competition law to avoid contractual restrictions having effect in its internal market. The licensed technology might be a required input for the production of its exportations; having access to such technology could also foster new developments in this area within the country, the business activities and international expansion of its nationals might be hinder by the license restrictions; the restrictions might unduly limit parallel importations and goods supply for the internal market, etc. In that sense, despite concluding the license agreement outside of the country promised to a single seed grower, if the competition within the importing country market is being distort, its laws are applicable to the agreement or abusive conduct and might tackle international segmentation of markets.

The concentration in the seed market and the imposition of abusive license agreements has different repercussions in each country due to differences in matters like the approvals for the commercialization of genetically engineer food, the importance of agriculture within the states' economy, the relevance of encouraging foreign investment, the need for technology transfer agreements, etc. These nuances must be weight when addressing the effects of the licenses granted by multinationals to local undertakings. Nonetheless, an approach to how other jurisdictions address the anticompetitive concerns arising from abusive license agreements provides valuable insights.

54 Daniels, Тімотнy P., “Keep the License Agreements Coming: The Effects of J.E.M. Ag Supply, Incorporated v. Pioneer Hi-Bred International, Incorporated on Universities' Use of Intellectual Property Laws to Protect Their Plant Genetic Research”, 2003, BYU Educ. \& L.J. 771 Available at: http://digitalcommons.law.byu.edu/elj/vol2003/iss2/11

55 Conde Gallego, Beatriz, "The principle of exhaustion of rights and its implications for competition law", International Review of Intellectual Property and Competition Law, 2003, 34(5), 473-502.

56 Ibid., 7.

57 Ibid., 9. 


\section{National approaches}

This section describes the approaches taken in the European Union, U.S, Brazil and Argentina regarding license agreements establishing territorial or post-sale restrictions affecting the internal market of each country.

\section{I. EUROPEAN Union}

The agricultural sector is the paramount for the implementation of the European Union (E.U) itself. It deserved particular consideration in the TTFEU whereby it was subjected to special competition rules ${ }^{58}$. In addition, the European seed industry is the biggest in the word but it is also highly concentrated ${ }^{59}$. In 2014, traits supply for the development of seed varieties was centered in six major companies, while, at the downstream level, there were around 7000 seed related companies, between growers, multipliers and retailers located mainly in Poland and Romania ${ }^{60}$.

According with a report issued by the European Competition Network in 2012, there have been isolated cases of anticompetitive behavior in the seeds market ${ }^{61}$. One in Portugal ${ }^{62}$ and another in Spain ${ }^{63}$ related with license agreements, but no pronouncement was made by any European authority in those cases. Nevertheless, the European Commission in two cases related with restrictions to the exportation established in licenses of P.B.R. addressed two main issues: i) the difference between sole license agreements and exclusive licenses with absolute territorial protection and; ii) the consideration of the effect of a cluster or bundle of restrictive contracts concluded by several undertakings at the same level of the value chain.

In LC Nungesser KG and Kurt Eisele v Commission, Mr. Eisele was the exclusive licensee for the production and commercialization of maize varieties in Germany. The licensor agreed not sale directly nor authorize third parties to sale maize varieties in Germany. By threats of legal enforcement of IP rights issued in Germany, parties systematically prevented the importation of maize purchased from the licensor in France ${ }^{64}$. Constructing Article 85(1) Treaty Establishing the European Community (ЕССT), the Court of Justice of the European Union (CJEU) distinguished between open exclusive license agreements and exclusive licenses with

58 Cf. Article 42 and 43(2) tтfeu. See also Parliament and Council Regulation (EU) n. ${ }^{\circ} 1308 / 2013$ Establishing a common organization of the markets in agricultural products. [2013] OJ L 347.

59 Mammana, Ivan, "Concentration of market power in the EU seed market", 2014, Study commissioned by the greens/EFA group in the European parliament. Available at: http://www.esporus.org/recursos/Documents\%20interessants/Documents/Seeds-study_UK_28-01V3.pdf 60 Ibid., 21.

61 European Competition Network. Report on competition law enforcement and market monitoring activities by European competition authorities in the food sector, 2012. Available at: http://ec.europa.eu/competition/ecn/food_report_en.pdf

62 Ibid., $\$ 138$.

63 Ibid., $\$ 201$.

64 Case 258/78 (n. 25) \$8. 
absolute territorial protection ${ }^{65}$. The formers are not by themselves incompatible with the Article 85(1), they may encourage the development of the technology licensed ${ }^{66}$. To the opposite, exclusive licenses extended to no signatories, due to the absolute territorial protection agreed, "in order to enable parallel imports to be controlled and prevented results in the artificial maintenance of separate national markets, [are] contrary to the Treaty" ${ }^{\prime 67}$. All the more, considering that the P.B.R. were exhausted once the maize varieties were sold in France.

In the same case, the parties argued the application of Article 85(3) ЕсCт because the territorial exclusivity provided the security required for the licensee to enter the German market. That is, it improved the production and distribution of goods in Germany. This argument was rejected by the cjeu holding that "absolute territorial protection manifestly goes beyond what is indispensable for the improvement of production or distribution or the promotion of technical progress" 68 .

The second case was referred by the Commercial Court of Liège for the interpretation of Article 85(1). The agreement was celebrated between a seed breeder Louis Erauw-Jacquery SPRL and a seed propagator, La Hesbignonne, for the propagation and sale of basic seed which exportation was prohibited. To the question of whether such restriction infringed Article 85(1) ECCT, the CJEU answered in the negative acknowledging that it is a measure for the breeder to control the basic subject-matter of its right ${ }^{69}$. The basic seed is indispensable for the propagation of the protected plant variety, if it can be freely reproduced, there would be no prize for the creation of new varieties ${ }^{70}$.

The license in the case above also fixed the price of the seed, the same price was agreed with every propagator the plant breeder conclude agreements with. It could have the effect of a horizontal cartel agreement. Article 85(1) prohibits any agreement which directly or indirectly fix prices. However, the agreement would be subject to Article 85(1) only if it affected trade between Member States to an appreciable degree ${ }^{71}$ which was to be decided by the national authority taking into account, three factors: i) whether the agreement is part of a bundle of similar contracts; ii) plant breeder's market share in regard with the seed; and iii) producers ability to export the seed (not the basic seed but its offspring) ${ }^{72}$.

To sum up, the CJEU has up held exclusive license agreements by which the parties establish certain territorial or commercial restrains to safeguard the incentives for them to invest in the development of new technologies and disseminate that technology. Complete protection from third competitors, does not deserve

69 Case C 27/87. sprl Louis Erauw-Jacquery v La Hesbignonne SC. [1988] ECR $01919-1935, \$ 11$.

70 Ibid., $\$ 10$.

71 Ibid., $\$ 17,19$.

72 Ibid., $\$ 18$. 
the same treatment because its detrimental effects on the endeavors of third parties threaten the functioning and competitiveness of the entire market. Additionally, the market may be affected by combine effect of a bundle of restrictive agreements, if the parties involved on those agreements have a significant market share in regard with a particular seed.

\subsection{United States}

The antitrust assessment of license agreements within the transgenic seed industry in the U.S. is complex, there are many intertwine considerations regarding the regulatory framework within the U.S. and its application in the international level. In the first place, many of the biggest transgenic seed markets are incorporated there, also the patents granted by the United States Patent and Trademark Office are licensed by these companies on worldwide bases to seed growers. The U.S exports the raw materials for the international transgenic seed market and the ones derived from it: innovation, genetic traits, and transgenic seed.

In the second place, innovations related with the transgenic industry are over protected through IP rights. It has reinforced the market power of multinationals in the international market. The U.S offers a threefold system to protect the developments achieve in the transgenic seed industry: Firstly, microorganism and genes are patentable subject matter ${ }^{73}$; secondly, sexually reproduced plant varieties are protectable under utility patents ${ }^{74}$; and thirdly, new plant varieties can be safeguard under the 1970 Plant Variety Protection Act. None of these IP rights excludes the issuance of another over the same matter ${ }^{75}$. Naturally, all those IP rights can be licensed and are perfect tools to gain market power.

In addition, the case of Bowman v. Monsanto patronizes license prohibitions of reutilizing seed, as the exhaustion doctrine forbids farmers to copy the patented product. Even though the latter case of Quanta Computer Inc. v. LG Electronics Inc. could be construct as entitling the reutilization of transgenic seeds ${ }^{76}$. In the latter, the Supreme Court held that the sale of an item embodying the essential features of the invention, and which only reasonable use is to practice the invention, exhaust patents rights ${ }^{77}$. This, could mean that by selling seeds containing genetic trait, IP rights over it are exhaust and farmers could reuse the seed, as it is its reasonable intended purpose; Quanta Computer did not address the issue of self-replicating technologies, as was the case in Bowman v. Monsanto where the Supreme Court make clear that its decision was limited to genetically modified

73 U.S. Supreme Court. Diamond v. Chakrabarty, 447 U.S. 303 (1980) 447 U.S. 303.

74 Cf. Plant Patent Act of 1930.

75 Cf. U.S. Supreme Court. J. E. M. Ag Supply, Inc. v. Pioneer Hi-Bred International, Inc. 534 U. S. 124 [2001].

76 U.S. Supreme Court. Quanta Computer Inc v. LG Electrics Inc. Quanta Computer, Inc. v. LG Electronics, Inc. 553 U.S. 617 [2008].

77 Ibid., 18. 
soybeans ${ }^{78}$. Therefore, until the judgement regarding the soybeans is overruled, the exhaustion does not allow farmers to reuse seeds but it does entitle IP right holders to charge fees.

The above issues obstruct the assessment of license practices in the transgenic seed market within the U.S. There have being attempts to evaluate possible violations of the Sherman Act by Monsanto's license agreements by the Department of Justice (DOJ); however the investigation was closed without initiating any legal action against the company ${ }^{79}$. This despite of the U.S. Department of Justice issuing guidelines for the licensing of IP right under which the practices of the company would deserve further inquiries ${ }^{80}$.

Regarding the assessment of the transgenic license terms in the international market, U.S is one of the few countries having a statute stablishing the requirements to judge under its competition law conducts originated abroad. The Foreign Trade Antitrust Improvements Act of 1982 (FTAIA), clarify when an agreement or abusive conducts that had restricted trade with foreign nations trigger the application of the Sherman Act. Following the FTAIA, it would happen when such conducts have a "direct, substantial, and reasonable foreseeable effect in import commerce from other nations or in export commerce of a person in the United States"

The FTAIA has not been interpreted uniformly, courts disagree on whether it stablish subject matter jurisdiction or whether its requirements relates to the merits of the claim. Equally, there are different interpretations as to what is a direct, substantial and reasonable foreseeable effect in the commerce or trade of the U.S. This disagreement about the construction of the FTAIA impede the application of U.S. antitrust regime to license agreements affecting the internal market of that country as the threshold for courts hearing these cases is not clear ${ }^{82}$. Moreover, the application of the FTAIA and, consequently, of the Sherman Act to address anticompetitive behavior of U.S. companies exclusively affecting foreign markets has been denied explicitly.

In the case of United States v. LSL Biotechnologies, the Court of Appeals of the Ninth Circuit hold that it lacks subject matter jurisdiction under the FTAIA because the conduct did not have a direct effect on U.S. commerce ${ }^{83}$. Due to an agreement between LSL Biotechnologies and Hazera Quality Seeds, the later agreed not to

78 Bowman v. Monsanto (n. 28) 10.

79 Monsanto Notified that U.S. Department of Justice Has Concluded Its Inquiry. Available at: http://www.monsanto.com/newsviews/pages/monsanto-notified-that-us-department-ofjustice-has-concluded-its-inquiry.aspx Accessed 29/7/2016.

80 U.S. Department of Justice. Federal Trade Commission Antitrust Guidelines for the Licensing of Intellectual Property. [1995]. Available at: https://www.ftc.gov/sites/default/ files/attachments/competition-policy-guidance/0558.pdf

81 Act of 1982 (ftaia). 15 U.S. Code $\$ 6 a-$ Conduct involving trade or commerce with foreign nations.

82 Lu, Diane, "In the Face of Strong Patent Rights: Using the Foreign Trade Antitrust Improvements Act to Combat Patent Abuse in International Commerce”, BUJ Sci. \&. Tech. L., 21, 2015, p.136.

83 U.S. United States v. LSL Biotechnologies, 379 F.3d 672, 680 (9th Cir. 2004). 
import long shelf-life tomato seeds into the U.S., which was reserved exclusively for LSL. The Court of Appeals reasoned that a direct effect on trade means an immediate consequence in the defendant activity banning him from engaging in trade. As there was no proof of Hazera having any alternative technology to preserve tomatoes fresh, nor any indication of it being able of developing it in a foreseeable term, "any innovation that Hazera would bring to American consumers is speculative at best and doubtful at worst. An effect cannot be "direct" where it depends on such uncertain intervening developments" ${ }^{\prime 4}$.

To the opposite, the Court of Appeals of the Seventh Circuit in the case MinnChem Inc. v. Agrium Inc ${ }^{85}$ rejected the above interpretation of the FTAIA arguing that there is a direct effect whenever the conduct has "a reasonably proximate causal nexus" ${ }^{86}$ with the effect in the American market; arguing that the aim of the U.S. antitrust law is not to punish all whom it can catch but only those behaviors having undue consequences in the U.S. market ${ }^{87}$.

In addition to the direct, substantial and reasonable foreseeable restriction to U.S. trade, the plaintiff has to stablish that the measure gives rise to its claim. The effect on the U.S. commerce must have a causal relationship with the damage suffered by the plaintiff. In the case of Lotes Co Ltd v. Hon Hai Precision Industry Co is illustrative $e^{88}$, the defendant refused to grant a license over a standard essential technology foreclosing the plaintiff from manufacturing and importing devices to the U.S. Although the direct, substantial and reasonable foreseeable restriction on U.S. trade was stablished, the court refused to assess the conduct of the American company. Following the court, the FTAIA made clear that "to American exporters (and to firms doing business abroad) that the Sherman Act does not prevent them from entering into business arrangements [...], however anticompetitive, as long as those arrangements adversely affect only foreign markets" $"$.

As a result, U.S regulatory framework may facilitate anticompetitive license practices, as multinationals holders of IP rights issued in this country have a strong protection while face reduce possibilities of being prosecuted for engaging in anticompetitive behavior abroad. This has as potential effect of foreclosure of foreign open markets ${ }^{90}$. An American IP holder might impose exporting prohibitions in its license agreements creating an artificial division of international markets, in countries that might be open to parallel imports. Therefore, the whole burden of chasing international anti-competitive agreements, lies on the importing country.

84 Ibid.

85 U.S. Minn-Chem, Inc. v. Agrium, Inc., [683 F.3d 845] (7th Cir. 2012).

86 Ibid., 858.

87 Ibid.

88 U.S. Lotes Co Ltd v. Hon Hai Precision Industry Co. 13-2280, 2014 WL 2487188

at ${ }^{*} 1$ (2d Cir. June 4, 2014).

89 Ibid.

90 Conde Gallego, B., (n. 55) 7. 


\subsection{BRAZIL}

In contrast with most nations, which adopt reactive measures, Brazil opted for a preventive approach to deal with the hazards arising for technology transfer agreements and its impact within its internal market. In accordance with Article 90 of the Brazilian Antitrust Act, a technology transfer agreement constitutes a concentration act subject to approval by Administrative Council for Economic Defense $(\mathrm{CADE})^{91}$. It will assess whether the act poses a substantial an unjustified restriction to competition by considering the rationale of the agreement, its real impact on the internal market while considering the importance of accessing high technology inputs and tools for the development of the market ${ }^{92}$. Missing the notification, the parties might face high fines and the agreement could be null.

The CADE has appraised several licenses regarding traits of soya ${ }^{93}$, the most cultivated genetically modified seed in Brazil. In 2012 Monsanto do Brasil Ltda intended to conclude agreements with five seed growers in Brazil for the development, multiplication and commercialization of basic seeds containing technology Intacta RR2 PRO making soya resistant to glyphosate and insects. Those agreements gave Monsanto access to information elaborated during the stages of development and field test of the new varieties the growers might create. Albeit the agreements were not exclusive and the growers were entitled to sublicense the technology provided by Monsanto, such sublicenses were subject to regulations provided by in the original licenses. Based on the huge influence Monsanto would gain over grower's business $^{94}$ as well as the low incentives left for them to develop competing technologies, the agreements were rejected by the $\mathrm{CADE}^{95}$.

Several aspects of the Brazilian law stand out from the general approach to licenses agreements and their impact in the structure of the internal market, although there is no complete consensus about them. First, the perspective of licenses agreements as merger submissions or acts of concentration capable of harming the structure of the market is disputed. Article 90 of the Brazilian antitrust act describes as acts of concentrations acquisitions and mergers; however, license agreements do not fit within these categories. The majority position in the approval requested by Monsanto do Brazil Ltda and Don Mario Sementes Ltda ${ }^{96}$, agreed that a corporation could control another through the obligations and commitments included

91 Antitrust Act 12.529/2011. Article 90.

92 Barrios, LucAs, "O contrato internacional de transferência de tecnologia e o Direito da Concorrência no Brasil: análise à luz da recente jurisprudência do Cade", Revista de Defesa da Concorrência, 2014, 2(2), pp. 128-129.

93 Cf. Brazil. cade. Monsanto do Brasil Ltda - Syngenta Proteção de Cultivos Ltda Administrative Process n. ${ }^{\circ}$ 08012.002870/2012-38. Monsanto do Brasil Ltda - Nidera Sementes Ltda AC. n. ${ }^{\circ} 08012.006706 / 2012-08$. Monsanto do Brasil Ltda Cooperativa Central de Pesquisa Agrícola AC n.o 08700.003898/2012-34. Monsanto do Brasil Ltda Bayer S.A. AC n. ${ }^{\circ} 08700.004957 / 2013-72$.

94 Barrios, L., (n. 92).

95 Ibid.

96 Brazil. cade. AC n.o 087000.003937/2012-01. Councillor Alessandro Octaviani Luis. 
in licenses. The dependence of one party on the technology provided by another might lead to give the later control over the former, create a form of external control, despite of not using the traditional means to take over a business ${ }^{97}$.

Second, the importance of preserving the market open for the development of new technologies and seed varieties is paramount within approval of the license agreements by the CADE. The license between Monsanto do Brasil and Don Mario Sementes Ltda. contained a system of rewards and rebates, which might discourage the latter of implementing third party technologies and from developing its own, as the ones provided by Monsanto would be more profitable ${ }^{98}$. Although the exclusive use of Monsanto's technology was not explicit, the real effect of the rebates was to barrier the entrance of competitors with their own seeds ${ }^{99}$. In addition, the CADE pointed at the relevance of applying antitrust law in coherence with public polices implemented to promote the development of biotechnology in Brazil ${ }^{100}$.

And thirdly, the doctrine in Brazil has notice that despite the fact that those agreements are concluded between the affiliates of multinationals incorporated in Brazil to be effective therein, they have an international element derived from the fact that those licenses "directly involve the seizure of large international economic groups and, indirectly, the international technology flow." 101

Although the standard for the approval of license agreements is high, it is not impossible to fulfil it. On January 2016, the CADE approved an agreement enabling Bayer to develop, produce and commercialize the Intacta Pro RR2 Technology. The approval was conditioned to modifications in the royalty payment method. Initially, the mechanism included a rebate for Bayer in case of producing certain percentage of Monsanto's soya, meaning that a competitor of Monsanto would have to adjust its price cover the rebate; it created a burden for the entry of competing technologies into the market ${ }^{102}$. Moreover, the initial agreement gave Monsanto the right of first refusal in case Bayer were for sale, with the modification ordered by the CADE, this clause was eliminated from the contract. Once again, the grounds for the modifications was avoiding any kind of external control on Bayer from Monsanto.

\subsection{Argentina}

The dispute over the transgenic seed market in Argentina illustrates the anticompetitive issue addressed here. That is, the use of license agreements to secure the

97 Ibid., $\$ 28-33$.

98 Ibid. cade. AC n. ${ }^{\circ}$ 087000.003937/2012-01. Councillor Eduardo Pontual Ribeiro, $\$ 58$.

99 Ibid., $\$ 61$.

100 cade. AC n. ${ }^{\circ}$ 087000.003937/2012-01. Councillor Alessandro Octaviani Luis, $\$ 36$

101 Barrios, L., (n. 92) 132.

102 Brazil. cade. ACNo.08700.004957/2013-72. Monsanto do Brasil Ltda Bayer S.A. Councillor Alessandro Octaviani Luis. AC. \$145 ss. 
payment of royalties from each party involved in the production of transgenic seeds and derivate products pursuant the enforcement of IP rights, in this case granted in foreign nations, while restricting international trade.

In 2005, three cargoes of soy meal from Argentina were detained in the port of Amsterdam due to the alleged infringement of a European patent granted to Monsanto, relating to 'Glyphosate tolerant 5-enolpyruvylshikimate-3-phosphate synthases' ${ }^{103}$, the Round Up Ready technology (R.R. technology). Monsanto initiated similar actions in England, Spain and Denmark ${ }^{104}$. The proceedings in Holland gave rise to a judgement by the cjeu holding the protection granted by the Directive 98/44/EC ${ }^{105}$ did not cover the soy transformed into flour because the RR genes would not perform their function of glyphosate tolerance anymore ${ }^{106}$. Monsanto withdrew its claims after reaching a settlement ${ }^{107}$.

The international trade of soy and its derivatives is paramount for Argentinian economy, as it is the main exportation product, $90 \%$ of the soy planted contains the RR technology, which was introduced in the country by Monsanto in the 1990 's ${ }^{108}$. The importance of protecting its international trade move the government of Argentina to intervene before the CJEU, the judicial authorities in Holland and to initiate proceedings before the National Commission for the Defense of Competition in Argentina (NCDC). The Government argued that Monsanto's lawsuits in Europe constitute an abuse of its dominant position infringing the Antitrust Act n. ${ }^{\circ} 25.156$ as it was generating uncertainty around the legality of the exportations of Argentinian soy to Europe.

The NCDC agreeing with the government issued a resolution to investigate the case $^{109}$. On appeal, the Federal Court of Appeals for Civil and Commercial Matters (Cámáaa Civil y Comercial Federal Sala III) did not find sufficient evidence of Monsanto's dominant position, upheld Monsanto's argument of the lawsuits being a legitimate action to enforce its legal rights within the European jurisdiction, and revoked the previous decisions ${ }^{110}$.

103 Case C-428/08. Monsanto Technology LlC v Cefetra BV., 2010, eCr I-06765.

104 Carlos Correa. Monsanto vs. Argentina, 2006, Le Monde Diplomatique [El Diplo]. Available at: http://www.insumisos.com/diplo/NODE/813.HTM

105 Cf. Article 9. Council Directive 98/44/EC of 6 July 1998 on the legal protection of biotechnological inventions, 1998, O.J. L 213/13.

106 Case C 428/08. (n. 103) $\$ 46$.

107 The Netherlands. The Hague District Court. Monsanto Technology Llc v. Cefetra B.V., The State of Argentina et al. and Monsanto Technology LLC v. Vopak Agencies Rotterdam B.V. and Alfred C. Toepfer International GmbH, Docket Decision, 23 June 2010, Case n. ${ }^{\circ}$ HA ZA 05-2885 and HA ZA 06-2576.

108 Instituto de Investigación Económica y Política ciudadana Isepci. La Reforma de la Ley de Semillas en Argentina. Análisis de la Propuesta del Gobierno y sus Principales Impulsores. [2014] ISEPCi. Available at: http://www.isepci.org.ar/descargas/publicaciones/ la-reforma-de-la-ley-de-semillas-en-argentina-analisis-de-la-propuesta-del-gobierno-y-sus-principalesimpulsores_117.pdf 4 .

109 Argentina. National Chamber of Appeals in Civil and Commercial Federal Chamber III. "Monsanto Company s/ Apelación Resolución Comisión Nacional de Defensa de la Competencia. Acumulada”. File number 638/2008.

110 Ibid. 
More recently, Monsanto has celebrated two kinds of contracts to secure the payment of biotechnology fees. First, under the Extended Royalty System (ERS), seed growers agree to pay an extra fee for reusing the seed; the grower also has to inform quantities of seed harvested and reused. Argentinian law does not endorse those agreements. The Law of Seeds allows farmers to reuse seed from previous harvest ${ }^{111}$, while under the ERS the use of a protected variety is subject to fees and prior authorizations. In that sense, the RES is closer to UPOV 1991, where farmer's privilege is no longer a compulsory but optional for each country to implement ${ }^{112}$. Therefore, the ERs legal support in Argentina lies in the parties' will to conclude such an agreement rather than in the exercise IP rights.

The second kind of agreements Monsanto has implemented, forces collectors and exporters to oversight the payment of fees and fine those growers or farmers refusing to pay. The oversight system has two parts: one, when farmers and growers agree to pay a fee for the use of the technology when purchasing the seed from the authorized retailers or when delivering the grain to authorized collectors and exporters ${ }^{113}$. The other, when collectors and exporters test grain deliver by farmers and growers searching for Monsanto's technology; if such technology is found, farmers are charged unless they probe they already payed; the fee could even be discount from the grain price ${ }^{114}$. Collectors and exporters also have to store the grains apart from other not containing the RR technology, which implies costly modifications on their facilities ${ }^{115}$.

Due to the pressure created by those agreements in the downstream market, in 2015, the Association of grain collectors, or gathering companies, in Argentina resort to the judiciary arguing that the agreements impose anticompetitive restrictions on their business in violation of the Antitrust Act n. ${ }^{\circ} 25.156$. The Association alleged that Monsanto was abusing of its dominant position to create a cartel of collecting companies, because only those who agree to its terms could gather soy grain from farmers and export it without risk of facing lawsuits abroad ${ }^{116}$. In June 2016, the Federal Court for Civil and Commercial Matters denied to hear the case alleging lack of jurisdiction. The authority held that the competence to judge

111 Argentina. Law No.20.247. Law of Seeds and Phytogenetic Creations. 30/3/73. Available at: http://servicios.infoleg.gob.ar/infolegInternet/anexos/30000-34999/34822/texact.htm\#1

112 Cf. Article 5(3) upov1978 and Article 15 upov1991. See also: Anabel Marin. El futuro de las semillas y la agricultura en Argentina. [2014]. Centro Steps para America Latina. Available at: https://stepsamericalatina.org/el-futuro-de-las-semillas-y-la-agricultura-enargentina-tecnologias-actores-y-derechos-de-propiedad/

113 Rossi, Hugo, "Los nuevos contratos de licencia de uso de soja: ¿cómo son? ¿Qué implicancias tienen?”, 2014, Consultor Agropecuario n.o 11. Errepar. Available at: http:// www.rossiamadeo.com.ar/\#!blogger-feed/c1 ktv/post/5790432689409546181

114 Argentina. Cámara Civil y Comercial Federal- Sala III. Com 15824/2015/CA1 "Federación de Centros y Entidades Gremiales de Acopiadores de Cereales c. Monsanto Argentina SA y otros s. amparo”. Buenos Aires, 2 de junio de 2016.

115 Ibid.

116 Ibid. 
antitrust issues belong to the NCDC; the association should have pursued an administrative process, the final decision of which could be subject to judicial control ${ }^{117}$.

Equally, the Agrarian Federation of Argentina (FAA in its Spanish acronym) report Monsanto's anticompetitive agreements before the $\mathrm{NCDC}^{118}$. FAA once again argues that Monsanto's is using its dominant position to secure the payments of fess over a technology that is not protected by Argentinian laws, by concluding anticompetitive agreements that restrict collectors commercial and export activities $^{119}$. NCDC has not render a decision yet.

The case law in Argentina regarding abuse of dominance to impose anticompetitive restrains in downstream markers is scarce and even more regarding abusive license agreements. Still, the NCDC will have to address paramount issues to decide FAA's complain. For instance, whether the agreements could be within the scope of the IP rights. Monsanto does not have a patent over the RR technology ${ }^{120}$; however, there is no certainty about patents it might held over the Intacta trait, nor over plant varieties incorporating that technology. The NCDC will have to evaluate Article 38 of the Argentinian Patent law prohibiting of ancillary restrains such as exclusive grant back clauses and any other that might be prohibited under the Antitrust Act ${ }^{121}$. Another relevant issue to consider in the complaint by FAA is the international reach of the principle of exhaustion in Argentina. According with its Patent Law, once the item containing the patented technology is legally sold anywhere in the world it can be freely traded in Argentina ${ }^{122}$.

\subsection{Assessment}

The case-law above shows that the use of license agreements by multinationals to implement exploitative system within the market of seeds is a real problem, even if still there is no case fully addressing the issue. The E.U case-law has focused on preserving the competitiveness of the internal market; in the U.S the fulfilment of the criteria set up by the FTAIA has taken all the attention of the courts, while in Argentina the judiciary has refused to hear the cases alleging procedural flaws. Within the jurisdictions analyzed, Brazil is the only one which has actually considered the anticompetitive effects that restrictive licenses agreements might have in its seed market and for the development of new technologies. However, it is possible

117 Ibid.

118 faA Prensa. faA y Sus Entidades Asociadas Ampliaron Denuncia Contra Monsanto, 2016. Available at: http://www.FAA.com.ar/Contenido/noticia7659.html\#.V6dSeU3hDIU

119 Ibid.

120 Argentina. Cámara Nacional de Apelaciones en lo Civil y Comercial Federal. Causa n. ${ }^{\circ}$ 8.044/07/CA1 . Monsanto Technology LLC c/ Instituto Nacional de la Propiedad Industrial s/ denegatoria de patente.

121 See Law 24.481 on Patents and Utility Models. March 20, 1996. Gazette: 22/03/1996.

122 Cf. Article 36(c). Law 24.481 on Patents and Utility Models. 
to gather significant issues to be considering when evaluating license agreements related with seeds and genetic traits under national competition law regimes.

1. The case of United States v. LSL Biotechnologies points at the importance of weighting the relevance of the technology licensed, and on whether it is feasible that alternative sources of technology will be developed in the foreseeable future. In cases where there are no alternative providers in the internal market, the license and segmentation of the market might not be detrimental of the internal market, as it provides a distribution system which enables the entrances of different products and technologies into the national market. This consideration will be pondered depending on the technological development each country has. In the case of the E.U. and the U.S, which are exporters of technology and seeds encouraging the dissemination of technology might not be as important as in Brazil, where the furtherance of biotechnology has led to the implementation of public policies.

2. The cases before the CJEU acknowledge that the prohibition against agreements which might affect the free commercialization of goods within the EEA is not absolute, the allocation of markets may have economic efficiencies. Two main issues have to be considered when assessing those efficiencies: i) whether the protection given by the agreement balances the incentives for the licensee to develop the technology licensed with the restrictions that might arise for the business of third parties; ii) consider the specific object of the restriction, to preserve the subject matter of P.B.R. such restrictions to commerce might be necessary for the actual existence of the right; while the restrictions upon the trade of products derived from the seed, as soy meal are not justified.

It worth noticing that those considerations are some of the basic principles for the assessment of technology transfer agreements which have been develop further under the Technology Transfer Block Exception Regulation ${ }^{123}$.

3. Giving the concentration in the upstream level of the seed market, the comprehensive dissemination of agreements with market allocation or selective distribution provisions could lead to coordinated practices within levels of the downstream market. It is paramount to assess the overall impact of several parties within the same level of the value chain being subject to equal distribution restrictions provided by in license agreements. Such combine effect was condemned by the CJEU in Louis Erauw-Jacquery, and it was also denounced by the FAA against Monsanto in Argentina.

4. From the Brazilian law it worth rescuing the view that license agreements may be an instrument for a company to take control over another, or at least on its core activities. Provisions imposing quality controls and promotion obligations on seed breeders and the stewardship of technologies, could have such effect. The underlying concern in here is the importance of preserving the licensee independence of technology transfer agreements Text with EEA relevance. [2014] OJ L 93/17. 
to conduct its own business as he sees fit, as well as encouraging him to develop its own technology, otherwise it will always need technology supplied from third parties, would never be able to compete in other markets.

\section{Conclusions}

At first sight, it may appear that the problems raised by restrictive license agreements would be easily solved if there was an international consensus on the doctrine of exhaustion of IP rights similar to the one adopted by the European Union. To say the least this solution is illusory, because such disparity of approaches gives countries certain maneuver over their internal market and control over parallel imports. Moreover, it could would have implications that at the implementation of such rule might hinder the development and dissemination of technology, as it will lead to an automatic increase on price on the first sale of the product in order to capture profits big enough as to fund further $R \& D$ activities. These high prices might be prohibitive for certain licensees.

Nevertheless, competition law is an appropriate to avoid abuses from IP right holders, but again, its application must be thoughtful and weight overall effect of the restrictive licenses. It is important to set thresholds for the application of national competition law regimes, to provide certainty and predictability. Naturally, the standard in which country will vary. As occurs in the U.S., providing protection for national IP right holder might be more important than opening the market for importations, while in Argentina and Brazil preserving the market open for the development national technologies might outweigh the protection of foreign companies.

Once the threshold for the application of the national competition law is overcome, the analysis should include key issues: whether the market allocation set on the agreement incentivizes the development of technology by the licensee or whether it obscures third party business activities; whether it imposes such a control over the licensee that is independence within the internal market and foreign markets where he could export the commodity are affected. It is also paramount to evaluate the effect that a bundle of licenses concluded by the dominant firm with various undertakings in the same level of the value chain might have in the market.

All in all, the segmentation of the seed market through license agreements is a flourishing discussion. Pending decisions in Argentina and India ${ }^{124}$, might enlighten other considerations not being deeply analyzed yet, like the impact of regulatory market approvals, the preservation of traditional knowledge in the development of plant varieties, the protection of biodiversity from being appropriated by P.B.R.

124 India. Competition Commission. Case n. ${ }^{\circ} 2$ of 2015 \& Case n.o 107 of 2015. Department of Agriculture, Cooperation \& Farmers Welfare v. Mahyco Monsanto Biotech (India) Limited February 10, 2016. Available at: http://www.cci.gov.in/sites/default/files/Ref\%20 02-2015\%20and\%20107-2015\%20-26(1)\%20order_10.02.2015.pdf 
and of organic crops from being contaminated with transgenic seeds. These matters must be added to the anticompetitive assessment of license agreements.

\section{REFERENCES}

\section{SeCONDARY SOURCES}

Argentina. Cámara Civil y Comercial Federal - Sala III. COM 15824/2015/CA1. "Federación de Centros y Entidades Gremiales de Acopiadores de Cereales c. Monsanto Argentina SA y otros s. amparo”. Buenos Aires, 2 de junio de 2016. Argentina. Cámara Nacional de Apelaciones en lo Civil y Comercial Federal. Causa n. ${ }^{\circ}$ 8.044/07/CA1. Monsanto Technology LlC c/ Instituto Nacional de la Propiedad Industrial s/ denegatoria de patente.

Argentina. Law n. ${ }^{\circ}$ 20.247. Law of Seeds and Phytogenetic Creations. 30/3/73. Available at: http://servicios.infoleg.gob.ar/infolegInternet/anexos/30000-34999/34822/texact.htm\#1

Argentina. National Chamber of Appeals in Civil and Commercial Federal Chamber III. "Monsanto Company s/ Apelación Resolución Comisión Nacional de Defensa de la Competencia. Acumulada”. File number 638/2008.

BASF Corporation. Clearfield Wheat Stewardship Guide 2014-2015 (2). Available at: http://agproducts.BASF.us/products/research-library/clearfield-wheatstewardship-guidelines.pdf

Benoit, David; Cimilluca, Dana; Mattioli, Dana, and Bunge, Jacob. "Dow Chemical and DuPont are in Advanced Talks to Merge", Wall Street Journal, 2015. Available http://www.wsj.com/articles/dow-chemical-and-dupont-arein-advanced-talks-to-merge-1449621799

Brazil. Cade. Monsanto do Brasil Ltda. - Nidera Sementes Ltda. AC. n. ${ }^{\circ}$ 08012.006706/2012-08.

Brazil. Cade. Monsanto do Brasil Ltda. - Syngenta Proteção de Cultivos Ltda. Administrative Process n. ${ }^{\circ}$ 08012.002870/2012-38.

Brazil. CADE. Monsanto do Brasil Ltda. Bayer S.A. AC n. ${ }^{\circ} 08700.004957 / 2013-72$.

Brazil. CAde. Monsanto do Brasil Ltda. Cooperativa Central de Pesquisa Agrícola. AC n. ${ }^{\circ} 08700.003898 / 2012-34$.

Bunge, Jaсов and Mattioli, Dana. "Bayer Proposes to Acquire Monsanto", Wall Street Journal, 2016. Available at: http://www.wsj.com/articles/bayermakestakeoverapproachtomonsanto 1463622691

Case C 193/83. Windsurfing Intl. Inc. v Commission [1986] eCr 611.

Case C 27/87. sprl Louis Erauw-Jacquery v La Hesbignonne SC. [1988] ECR $01919-1935$.

Case C-258/78. L. C. Nungesser v Commission. [1982] ECR 02015.

Case C-61/97. fDv v Laserdisken. [1998] ECR I-05171.

Case C428/08. Monsanto Technology LLC v Cefetra BV. [2010] ECR I-06765. 
Commission on Genetic Resources for Food and Agriculture. Food and Agriculture Organization of the United Nations. Potential impacts of genetic use restriction technologies (GURTS) on agrobiodiversity and agricultural production systems. [2001] FAO. Available at: ftp://ftp.fao.org/docrep/fao/meeting/015/aj627e.pdf Commission Regulation (EU) No 316/2014. March 21, 2014 on the application of Article 101(3) of the Treaty on the Functioning of the European Union to categories of technology transfer agreements Text with EEA relevance. [2014] OJ L 93/17.

Council and Parliament Regulation (EU) 1257/2012 of 17 December 2012. Implementing enhanced cooperation in the area of the creation of unitary patent protection [2012] OJ L 361/1.

Council Directive 98/44/EC of 6 July 1998 on the legal protection of biotechnological inventions. [1998] O.J. L 213/13.

European Competition Network. Report on competition law enforcement and market monitoring activities by European competition authorities in the food sector, 2012. Available: http://ec.europa.eu/competition/ecn/food_report_en.pdf

India. Competition Commission. Case n. ${ }^{\circ} 2$ of 2015 \& Case n. ${ }^{\circ} 107$ of 2015. Department of Agriculture, Cooperation \& Farmers Welfare v. Mahyco Monsanto Biotech (India) Limited February 10, 2016. Available at: http:// www.cci.gov.in/sites/default/files/Ref\%2002-2015\%20and\%20107-2015\%20 -26(1)\%20order_10.02.2015.pdf

Instituto de Investigación Económica y Política Ciudadana Isepci. La reforma de la Ley de Semillas en Argentina. Análisis de la propuesta del Gobierno y sus principales impulsores, 2014, IsEPCi. Available at: http://www.isepci.org.ar/ descargas/publicaciones/la-reforma-de-la-ley-de-semillas-en-argentina-analisisde-la-propuesta-del-gobierno-y-sus-principales-impulsores_117.pdf

International Service for the Acquisition of Agri-biotech Applications ISAA. ISAAA Brief 49-2014: Global Status of Commercialized Biotech/GM Crops: 2014. Available at: http://www.ISAAA.org/resources/publications/briefs/49/executivesummary/default.asp

Mammana, Ivan. "Concentration of market power in the EU seed market", Study commissioned by the greens/EFA group in the European parliament, 2014. Available at: http://www.esporus.org/recursos/Documents\%20interessants/ Documents/Seeds-study_UK_28-01V3.pdf

Marín, AnABel. "El futuro de las semillas y la agricultura en Argentina", Centro Steps para America Latina, 2014. Available at: https:/stepsamericalatina.org/ el-futuro-de-las-semillas-y-la-agricultura-en-argentina-tecnologias-actores-yderechos-de-propiedad/

Monsanto Technology/Stewardship Agreement (Limited Use License). 2016 In Monsanto. 2016тUg U.S. Technology Use Guide and Irm Overview (38). Available at: http://www.monsanto.com/products/documents/2016_tug_final.pdf 
Parliament and Council Regulation (EU) No 1308/2013 Establishing a common organization of the markets in agricultural products [2013] OJ L 347.

Phillips McDougall. "The Cost of New Agrochemical Product Discovery, Development and Registration in 1995, 2000, 2005-8 and 2010 to 2014. R\&D expenditure in 2014 and expectations for 2019, 2016”. Consultancy Study for CropLife International, CropLife America and the European Crop Protection Association. Available at: http://www.croplifeamerica.org/wp-content/ uploads/2016/04/Phillips-McDougall-Final-Report_4.6.16.pdf

Rossi, Hugo. "Los nuevos Contratos de Licencia de Uso de Soja: ¿Cómo son? ¿Qué implicancias tienen?", Journal Consultor Agropecuario n. ${ }^{\circ} 11$, Errepar, 2014. Available at: http://www.rossiamadeo.com.ar/\#!blogger-feed/c1ktv/ post $/ 5790432689409546181$

Syngenta Cp / Advanta (Case Comp/M.3465), 2004. Document n. ${ }^{\circ} 32004 M 3465$. OJ C 263/7.

The Netherlands. The Hague District Court, Monsanto Technology llc v. Cefetra B.V., The State of Argentina et al. and Monsanto Technology LLC v. Vopak Agencies Rotterdam B.V. and Alfred C. Toepfer International GmbH, Docket Decision, 23 June 2010, Case n. ${ }^{\circ}$ HA ZA 05-2885 and HA ZA 06-2576.

Treaty Establishing the European Community, of 10 November 1997. O.J. C $340 / 112$.

U. S. Department of Justice. Press Release. Justice Department Approves Monsanto's Acquisition of Dekalb Genetics Corporation. [1998] Available at: www.usdoj.gov

U.S. Court of Appeals of the Federal Circuit. Mallinckrodt, Inc. v. Medipart, Inc., 976 F. 2d 700 (1992).

U.S. Department of Agriculture. Genetically Engineered Crops in the United States. (2014). Available at: http://www.ers.usda.gov/media/1282246/err162.pdf

U.S. Department of Justice. Federal Trade Commission Antitrust Guidelines for the Licensing of Intellectual Property. [1995] Available at: https://www.ftc. gov/sites/default/files/attachments/competition-policy-guidance/0558.pdf

U.S. Lotes Co Ltd v. Hon Hai Precision Industry Co. 13-2280, 2014 WL 2487188 at $* 1$ (2d Cir. June 4, 2014).

U.S. Minn-Chem, Inc. v. Agrium, Inc., [683 F.3d 845] (7th Cir. 2012).

U.S. Supreme Court. Diamond v. Chakrabarty, 447 U.S. 303 (1980) 447 U.S. 303.

U.S. Supreme Court. J. E. M. Ag Supply, Inc. v. Pioneer Hi-Bred International, Inc. 534 U. S. 124 [2001].

U.S. Supreme Court. Quanta Computer Inc v. LG Electrics Inc. Quanta Computer, Inc. v. LG Electronics, Inc. 553 U.S. 617 [2008].

U.S. Supreme Court. Vernon Hugh Bowman v. Monsanto Company et al. 569 U. S. (2013).

U.S. United States v. LsL Biotechnologies, 379 F.3d 672, 680 (9th Cir. 2004). 
Books

Kloppenburg, Ralph Jack. First the seed: The political economy of plant biotechnology, University of Wisconsin Press, 2004.

JOURNAL ARTICLES

BARrios, Lucas. "O contrato internacional de transferência de tecnologia e o Direito da Concorrência no Brasil: análise à luz da recente jurisprudência do Cade", Revista de Defesa da Concorrência, 2014, 2(2).

Conde Gallego, Beatriz, "The principle of exhaustion of rights and its implications for competition law", International Review of Intellectual Property and Competition Law, 2003, 34(5), pp. 473-502.

Daniels, Тiмотнy P., "Keep the License Agreements Coming: The Effects of J.E.M. Ag Supply, Incorporated v. Pioneer Hi-Bred International, Incorporated on Universities' Use of Intellectual Property Laws to Protect Their Plant Genetic Research", 2003, BYU Educ. \& L.J. 771. Available at: http://digitalcommons. law.byu.edu/elj/vol2003/iss $2 / 11$

FIKentscher, WolfGang, "The Draft International Antitrust Code (DIAC) in the Context of International Technological Integration - The Institutional and Jurisdictional Architecture", Chi.-Kent. L. Rev., 1996, 72, p. 533.

Harl, NeIl E., "The Age of Contract Agriculture: Consequences of Concentration in Input Supply”, Journal of Agribusiness, 2000, 18(1), pp. 115-128.

Hennessy, David A. and Hayes, Dermot J., "Competition and Tying in Agrichemical and Seed Markets", Review of Agricultural Economics, 2000, 22(2), pp. 389-406.

Leach, Mark; Mesquita, Luiz and Downey, David, "Case study: Partnering strategies in a bio tech. world: The case of Dairyland Seed Company", The Journal of Business \& Industrial Marketing, 2001, 16(3).

Lence, SErgio H. and others, "Welfare impacts of intellectual property protection in the seed industry", American Journal of Agricultural Economics, 2005, 87(4), pp. 951-968.

Lim, Daryl, "Living with Monsanto", Michigan State Law Review, 2015, pp. 559-663.

Srinivasan, C. S. and Thirtle, Colin, "Potential economic impacts of terminator technologies: policy implications for developing countries", Environment and Development Economics, 2003, 8(01), pp. 187-205.

Westkamp, Guido, "Intellectual Property, Competition Rules, and the Emerging Internal Market: Some Thoughts on the European Exhaustion Doctrine”, 11 Intellectual Property L. Rev, 2007.

Winston, Elizabeth I., "Why sell what you can license?", George Mason Law Review, 2006, p. 14. 
Yusuf, MANsir, "Ethical issues in the use of the terminator seed technology", African Journal of Biotechnology, 2010, 9(52), pp. 8901-8904.

\section{BOOK CHAPTERS}

Cahoon, Richard S. "Licensing Agreements in Agricultural Biotechnology", in Intellectual Property Management Intellectual Property Management in Health and Agricultural Innovation: A Handbook of Best Practices, MIHR: Centre for the Management of Intellectual Property in Health Research and Development and Public Intellectual Property Resource for Agriculture PIPRA, 2007.

Forsyth, Miranda and Warwic, Rothnie. "Parallel Imports", en Steven D Anderman (ed), The Interface Between Intellectual Property Rights and Competition Policy, Cambridge University Press, 2007.

Hoвbes, Jill E., “The private sector: Mnes and smes”, in Smyth and others (eds), Handbook on Agriculture, Biotechnology and Development, Edward Elgar, 2014.

Neagley, Clinton H. Patent Licensing for Small Agricultural Biotechnology Companies. In Intellectual Property Management in Health and Agricultural Innovation: A Handbook of Best Practices, MIHR: Centre for the Management of Intellectual Property in Health Research and Development and Public Intellectual Property Resource for Agriculture PIPRA, 2007.

\section{Websites}

Carlos Correa. Monsanto vs. Argentina [2006] Le Monde Diplomatique [El Diplo]. Available at: http://www.insumisos.com/diplo/NODE/813.HTM

FAA Prensa. faA y sus entidades asociadas ampliaron denuncia contra Monsanto. [2016]. Available at: http://www.FAA.com.ar/Contenido/noticia7659.html\#. V6dSeU3hdiu

International Service for the Acquisition of Agri-biotech Applications. IsAAA Brief 49-2014: Top Ten Facts. Available at: http://www.ISAAA.org/resources/publications/briefs/49/toptenfacts/default.asp

Monsanto Notified that U.S. Department of Justice Has Concluded Its Inquiry. Available at: http://www.monsanto.com/newsviews/pages/monsanto-notified-that-us-department-of-justice-has-concluded-its-inquiry.aspx Accessed $29 / 7 / 2016$. 